\title{
IMMUNISATION OF LABORATORY ANIMALS AND CATTLE WITH NON-AGGLUTINOGENIC EXTRACTS OF BRUCELLA ABORTUS STRAIN 45/20
}

\author{
M. Sterne, Gladys Trim and E. S. Broughton \\ The Wellcome Research Laboratories, Beckenham, Kent, England
}

KILLED brucella organisms, whole, extracted or fractionated, can induce a substantial immunity in mice and guinea-pigs to challenge with virulent brucella (McEwen and Samuel, 1955; McDiarmid and Sutherland, 1957; Markenson, Sulitzeanu and Olitzki, 1962; Keppie, Witt and Smith, 1963; Pilet and Le Garrec, 1963; Ellwood, Keppie and Smith, 1967).

The great variety of procedures that have been used to measure protection in laboratory animals include methods giving a quantal response-such as death of mice after challenge (Smith et al., 1962; Milerová, 1969)—and those giving a graded response, which has been expressed by Markenson et al. as the ratio between the number of organisms found in spleens of non-immunised and of immunised animals after challenge. It is difficult to assess the relative merits of the various methods that have been advocated, because these differed in respect of the species of animal used, the number of vaccinations given, the routes of vaccination followed, the interval between vaccination and challenge, and the interval between challenge and the time when the degree of infection was estimated.

Because of the diversity of schedules that have been used to immunise laboratory animals and because of the paucity of data from comparative tests in cattle, it is doubtful whether the behaviour of a preparation in cattle can be predicted from its behaviour in laboratory animals. Indeed, a purified extract prepared by Paterson, Pirie and Stableforth (1947), which had been very effective in guinea-pigs, failed to protect cattle (Paterson and Pirie, 1948; McDiarmid, 1949).

In practice, cattle are usually immunised against brucellosis (contagious abortion) with a living vaccine made with the well-known attenuated strain 19. Alternatively, a suspension of whole killed cells of the rough Brucella abortus strain 45/20 emulsified in mineral oil has been used (McDiarmid and Sutherland; Roerink, 1967). Both vaccines are effective, when efficiently prepared. The living strain-19 vaccine, however, when used in adult cattle, induces the formation of serum antibodies, which interfere with the detection of naturally infected animals and their subsequent elimination from a herd. The emulsion vaccine, on the other hand, is, for most practical purposes, free from this defect, but provokes undesirable and by no means negligible local reactions. A purpose of the work reported here was to explore the possibility of developing a vaccine for cattle free from both these undesirable characteristics.

\section{MATERIALS AND METHODS}

Strains used

Brucella abortus $45 / 20$, the rough non-agglutinogenic variant isolated by McEwen and Roberts (1936), and Brucella abortus strain 544, a virulent smooth strain isolated by McEwen and used widely for challenging immunity to Br. abortus, were used.

Received 8 July 1970; accepted 15 Dec. 1970.

J. MED. MICROBIOL.-VOL. 4 (1971) 
Maintenance and reconstitution of strains. These were kept lyophilised. On reconstitution, they were streaked on the surface of solid media and the resulting growth was examined for homogeneity of colonial morphology.

\section{Culture medium}

Papain digest of horse muscle to give a total nitrogen concentration of 0.45 per cent.; yeast extract (Marmite) to 1 per cent.; fructose to 4 per cent.; $\mathrm{Na}_{2} \mathrm{HPO}_{4}$ (anhydrous) to 0.16 per cent. The $p \mathrm{H}$ was adjusted to 6.5 and the medium sterilised by filtration through Seitz-type pads.

Cultivating and harvesting. Strain $45 / 20$ was grown in deep culture with aeration for 3 days, harvested and left in the cold to settle to a final concentration of $c .800 \times 10^{9}$ cells per ml.

\section{Preparation of extracts}

Lot 171B1S1, which was eventually tested in cattle, was prepared as follows. Sodium dodecyl sulphate (SDS) was added to a suspension of live cells of strain 45/20 to a final concentration of 2.5 per cent. SDS and $1000 \times 10^{9}$ cells per $\mathrm{ml}$. This was held at $20^{\circ} \mathrm{C}$ for $24 \mathrm{hr}$, when an equal volume of 95 per cent. ethanol was stirred into the gelatinous mass, which was then centrifuged at $20^{\circ} \mathrm{C}$ and $1800 \mathrm{~g}$ for $2 \mathrm{hr}$; the supernatant was discarded. The fibrous deposit was taken up in $\mathrm{M} / 50$ phosphate-buffered saline at $p \mathrm{H} 7.5$ to the original volume, centrifuged as before and the deposit discarded.

The method was a modification of that used by Jenkin and Rowley (1965) for extracting protective antigen from Salmonella typhimurium. It differed in that the SDS extract was prepared from live organisms, and that its precipitation with alcohol followed, without preliminary clarification and dialysis. Finally, the buffer-saline extract of the alcohol precipitate was lightly centrifuged $(1800 \mathrm{~g})$ and the deposit was discarded.

Since lot 171B1S1 was not highly purified, the analyses can be regarded as establishing only upper limits for some components of the extract. For example, the fact that the undialysable lipid was 1.7 per cent. almost certainly excluded lipopolysaccharide complexes as components of the extract.

Preparation of oily emulsions. Thirty volumes of an aqueous solution or suspension of the preparation to be tested, to which Tween 80 (polyoxyethylene sorbitan mono-oleate) had been added to 1 per cent., was emulsified in 70 vol. of mineral oil containing Arlacel A (mannide mono-oleate) to 10 per cent.

\section{Tests of potency}

In mice. Male white Swiss mice of $16-20 \mathrm{~g}$ weight were vaccinated intraperitoneally and challenged intraperitoneally 4 wk later with 5000 organisms of strain 544 . They were killed $1 \mathrm{wk}$ later and each spleen was homogenised in $10 \mathrm{ml}$ of buffer solution, and $0.1 \mathrm{ml}$ of the homogenate was spread on horse blood agar plates. Colonies were counted after 3 days. Thus a "negative" spleen meant one containing less than 100 living organisms. The protection index (PI) used was that defined by Markenson et al. as the ratio of the number of organisms in the spleens of non-vaccinated mice to that in the spleens of vaccinated mice. In calculating the index, the geometric mean of the individual spleen counts was used and a " negative" spleen was assumed to contain 25 organisms.

In guinea-pigs. Male guinea-pigs weighing $250-300 \mathrm{~g}$ were vaccinated intramuscularly and challenged intramuscularly 60 days later with 5000 cells of strain 544 . Forty-two days later the guinea-pigs were killed and the organisms in each spleen counted and evaluated as described above.

In cattle. Virgin heifers free of brucellosis were vaccinated subcutaneously (day 0) in the middle of the neck and re-vaccinated on the opposite side 84 days later. They were artificially inseminated in the 3 -wk period commencing 14 days after the second vaccination, and challenged on day 197 with $15 \times 10^{6}$ organisms of strain 544 instilled into the conjunctivae. At this time the heifers were from 124 to 149 days pregnant. Agglutinating, complement fixing, and incomplete (Coombs) antibodies were determined before vaccination and at 
various times thereafter. At abortion or parturition, appropriate samples were examined for brucella by culture and, where this proved negative, by animal inoculation. A cow was considered infected if the level of agglutinins remained at more than 25 International Units for more than 21 days after calving or if brucellae were isolated from any tissue or secretion.

Chemical and physical examinations. These were carried out by conventional methods which will be specified in more detail in a later report.

\section{EXPERIMENTS}

Immunisation of mice and guinea-pigs with whole killed cells or with extracts of Brucella abortus strain 45/20

Since the target was the development of a non-agglutinogenic, non-reactive vaccine for cattle, the demonstration of protection in laboratory animals was considered significant only in so far as this could be correlated with protection

TABLE I

Immunisation of mice and guinea-pigs with whole killed cells of Brucella abortus strain 45/20

\begin{tabular}{|c|c|c|c|c|c|}
\hline \multirow{2}{*}{ Animal } & \multicolumn{3}{|c|}{ Vaccines used } & \multicolumn{2}{|c|}{$\begin{array}{l}\text { Results of challenge } \\
\text { after vaccination }\end{array}$} \\
\hline & Lot & How killed & Dose $\left(10^{9}\right)$ & $\begin{array}{l}\text { Number of } \\
\text { animals protected/ } \\
\text { number tested }\end{array}$ & $\begin{array}{l}\text { Protection } \\
\text { index }\left(10^{3}\right)\end{array}$ \\
\hline Mouse & 144 & Formaldehyde & 10 & $3 / 4$ & \\
\hline Mouse & 170 & Formaldehyde & 80 & $9 / 13$ & $4 \cdot 70$ \\
\hline Mouse & 170 & Formaldehyde & 8 & $5 / 5$ & $9 \cdot 20$ \\
\hline Mouse & 170 & Formaldehyde & 0.8 & $4 / 6$ & 0.90 \\
\hline Guinea-pig & 144 & Formaldehyde & 90 & $3 / 4$ & $2 \cdot 60$ \\
\hline Guinea-pig & 170 & Formaldehyde & 80 & $4 / 14$ & $0 \cdot 13$ \\
\hline Guinea-pig & 138 & Acetone & 80 & $2 / 4$ & 0.60 \\
\hline Guinea-pig & 139 & Ethanol & 80 & $0 / 4$ & 0.04 \\
\hline Guinea-pig & 140 & Phenol & 80 & $3 / 4$ & $2 \cdot 70$ \\
\hline Guinea-pig & $146 \mathrm{E}$ & Heat $\left(60^{\circ} \mathrm{C}\right)$ & 80 & $1 / 4$ & 0.01 \\
\hline Guinea-pig & 144 & Formaldehyde & $90^{*}$ & $4 / 4$ & 25.00 \\
\hline Guinea-pig & 139 & Ethanol & $80^{*}$ & $4 / 4$ & $25 \cdot 00$ \\
\hline Guinea-pig & 140 & Phenol & $80^{*}$ & $4 / 4$ & 25.00 \\
\hline Guinea-pig & $146 \mathrm{E}$ & Heat $\left(60^{\circ} \mathrm{C}\right)$ & $80^{*}$ & $4 / 4$ & $25 \cdot 00$ \\
\hline
\end{tabular}

$*$ = Emulsified in mineral oil.

of cattle. Whilst it is generally conceded that vaccines that fail to protect guinea-pigs are unlikely to immunise cattle, the converse does not hold, and preparations that protect laboratory animals do not necessarily induce satisfactory immunity in cattle. Dr B. Cunningham tells us that batches of living strain-19 vaccine or of killed 45/20 emulsion vaccine that failed to induce satisfactory immunity in guinea-pigs were inadequate when tested subsequently in cattle. On the other hand, the extract prepared by Paterson and Pirie proved ineffective in cattle although highly potent in guinea-pigs.

We hoped that it would be possible to screen non-living preparations of 
strain $45 / 20$ in laboratory animals for trial in cattle. Accordingly, a large number of preparations consisting of whole cells killed by different agents, and of extracts prepared in various ways, were tested in mice and guinea-pigs (tables I and II).

Thus (table I), mice and guinea-pigs vaccinated with killed whole cells of strain $45 / 20$ developed considerable resistance to subsequent challenge with virulent Brucella abortus. This resistance was much enhanced when suspensions emulsified in mineral oil were used.

TABLE II

Immunisation of mice and guinea-pigs with extracts of Brucella abortus strain 45/20

\begin{tabular}{|c|c|c|c|c|c|}
\hline \multirow[b]{2}{*}{ Animal } & \multicolumn{3}{|c|}{ Vaccines used } & \multicolumn{2}{|c|}{ Results of challenge } \\
\hline & Lot & How prepared & $\begin{array}{l}\text { Dose } \\
\left(10^{9}\right)\end{array}$ & $\begin{array}{l}\text { Number of } \\
\text { animals protected/ } \\
\text { number tested }\end{array}$ & $\begin{array}{c}\text { Protection } \\
\text { index }\left(10^{3}\right)\end{array}$ \\
\hline $\begin{array}{l}\text { Mouse } \\
\text { Mouse } \\
\text { Mouse } \\
\text { Mouse } \\
\text { Mouse } \\
\text { Mouse } \\
\text { Mouse } \\
\text { Guinea-pig } \\
\text { Guinea-pig } \\
\text { Guinea-pig } \\
\text { Guinea-pig } \\
\text { Guinea-pig } \\
\text { Guinea-pig } \\
\text { Guinea-pig }\end{array}$ & $\begin{array}{l}119 \\
125 \\
125 \\
126 \\
171 \text { B1S1 } \\
171 \text { B1S1 } \\
171 \text { B1S1 } \\
143 \text { AS } \\
143 \text { AS } \\
143 \text { AS } \\
147 \\
147 \text { S } \\
171 \text { B1S1 } \\
171 \text { B1S1 }\end{array}$ & $\begin{array}{l}10 \text { per cent. SDS } \\
50 \text { per cent. " Hederol" } \\
50 \text { per cent. " Hederol " } \\
5 \text { per cent. SDS at } 52^{\circ} \mathrm{C} \\
2.5 \text { per cent. SDS at } 20^{\circ} \mathrm{C} \\
2.5 \text { per cent. SDS at } 20^{\circ} \mathrm{C} \\
2.5 \text { per cent. SDS at } 20^{\circ} \mathrm{C} \\
4 \text { per cent. SDS at } 52^{\circ} \mathrm{C} \\
4 \text { per cent. SDS at } 52^{\circ} \mathrm{C} \\
4 \text { per cent. SDS at } 52^{\circ} \mathrm{C} \\
2.5 \text { per cent. SDS at } 37^{\circ} \mathrm{C} \\
147 \text { spun at } 20,000 g \\
2.5 \text { per cent. SDS at } 20^{\circ} \mathrm{C} \\
2.5 \text { per cent. SDS at } 20^{\circ} \mathrm{C}\end{array}$ & $\begin{array}{l}40 \\
40 \\
40^{*} \\
40 \\
80 \\
8 \\
0 \cdot 8 \\
90 \\
30 \\
10 \\
80 \\
80 \\
80 \\
80^{*}\end{array}$ & $\begin{array}{c}3 / 8 \\
5 / 8 \\
2 / 7 \\
2 / 8 \\
12 / 14 \\
1 / 6 \\
0 / 4 \\
3 / 3 \\
4 / 4 \\
3 / 3 \\
4 / 4 \\
3 / 4 \\
4 / 25 \\
7 / 17\end{array}$ & $\begin{array}{c}70 \cdot 00 \\
88 \cdot 00 \\
23 \cdot 00 \\
18 \cdot 00 \\
6 \cdot 40 \\
0 \cdot 33 \\
0 \cdot 11 \\
\cdots \\
\cdots \\
\ldots \\
17 \cdot 00 \\
2 \cdot 60 \\
0 \cdot 01 \\
0 \cdot 21\end{array}$ \\
\hline
\end{tabular}

* = Emulsified in mineral oil.

Most of the earlier experiments summarised in table II were done in mice. The calculation of the protection index was based on the numbers of organisms found in the spleens of mice 7 days after challenge. However, the numbers found in non-immunised controls 7 days after infection varied greatly from one experiment to another, with consequent wide fluctuations in the protection index. This created anomalies. For example, the potency of lot 125 relative to lot $171 \mathrm{~B} 1 \mathrm{~S} 1$ (the vaccine eventually tested in cattle) was 14 according to the ratio of protection indexes and 0.7 according to the ratio of " negative" spleens.

Because of such discrepancies in the estimations of relative potencies in mice-due probably to the restricted period of 7 days during which significant differences between immunised and control mice could be observed-most of the subsequent assays were made in guinea-pigs, despite the far longer duration of the test in these animals, in the expectation that scatter would be less and results more reproducible. 
Because of our doubts as to the significance of tests in mice and guineapigs the selection of preparations for trial in cattle was not based primarily on the results of tests in laboratory animals. The group of cattle inoculated with formalin-killed cells without adjuvant (lot 170) was included because such a vaccine had not previously been tested in cattle, and it was considered that the result might provide a base-line that could be a useful guide to future development. The extract (lot 171B1S1) was selected because it appeared to be devoid of lipopolysaccharide. Its analysis is given in table III.

TABLE III

Analysis of extract 17IBISI

\begin{tabular}{l|c|c}
\hline \multirow{2}{*}{ Substances present } & \multicolumn{2}{|c}{ Percentage dry weight } \\
\cline { 2 - 3 } & $\begin{array}{c}\text { before } \\
\text { dialysis }\end{array}$ & $\begin{array}{c}\text { after } \\
\text { dialysis }\end{array}$ \\
\cline { 2 - 3 } & $2 \cdot 4$ & $\ldots$ \\
Free amino nitrogen & $3 \cdot 9$ & $\ldots \cdot 3$ \\
Total amino nitrogen & $34 \cdot 0$ & $16 \cdot 4$ \\
Amino acids after hydrolysis & $15 \cdot 2$ & $24 \cdot 4$ \\
Protein (by Lowry) & $11 \cdot 3$ & $3 \cdot 2$ \\
Total lipid & $1 \cdot 7$ & $3 \cdot 2$ \\
Non-dialysable lipid & $48 \cdot 1$ & $49 \cdot 6$ \\
Carbohydrate & $\ldots$. & tr \\
Formic acid & n.d. & $\ldots$ \\
Amino-pimelic acid & n.d. & $\ldots$ \\
Amino-sugar & n.d. & $\ldots$ \\
Pentose & $1 \cdot 35$ & $\ldots$ \\
Sedimentation--S & & \\
\hline
\end{tabular}

$\operatorname{tr}=$ Trace; n.d. = not detected.

Carbohydrate, of which 57 per cent. was not dialysable, accounted for 48 per cent. of the dry weight. Hydrolysis yielded only glucose; no aminosugars were detected. It seemed unlikely, therefore, that the carbohydrate was derived from a capsular mucopolysaccharide. However, it might have represented the polysaccharide moiety of a glucoprotein. The fact that 80 per cent. of the sample sedimented as a single component in the ultracentrifuge suggested that much of the carbohydrate and protein found could have been associated in such a complex.

Only 1.7 per cent. of lipid remained after dialysis. It was unlikely therefore that any major component of the extract was either lipopolysaccharide or a lipopolysaccharide-protein complex - a suggestion already made doubtful by the absence of any but glucose residues after hydrolysis, and by the result of ultracentrifugation, which gave a sedimentation constant of $\mathrm{S}_{20} \cdot w=1.35$ for a component accounting for 80 per cent. of the extract.

Immunity elicited in pregnant bovines with various preparations of Brucella abortus strain 45/20

Four groups of animals were used to test three killed preparations of strain $45 / 20$ as follows. 
1. Lot 171B1S1 (table II) was a completely non-agglutinogenic, non-toxic extract of strain $45 / 20$, without adjuvant.

2. Lot 170 (table I) was a formolised whole cell suspension, without adjuvant.

3. "Duphavac" (Roerink), a commercially available oil emulsion vaccine known to protect cattle effectively, was used as a positive control.

4. A group consisting of non-immunised animals was included as a control on the virulence of the strain used as a challenge.

There was little difference between the efficacies of lot 170 and 171B1S1 in laboratory animals (tables I and II). Both had induced higher immunity in mice than in guinea-pigs. Lot 171B1S1 protected 12/14 mice against challenge and had a protection index in these of 6400 . In guinea-pigs it protected 4/25 and had a protection index of 10 .

Group 1 consisted of five animals vaccinated subcutaneously with extract 171B1S1, in saline. None showed any local or general reactions; none developed complement-fixing or agglutinating antibodies; two only showed low Coombs' titres 38 days after the second vaccination; none aborted; three remained uninfected.

Group 2 consisted of five animals vaccinated subcutaneously with formolised cell suspension lot 170 . Local reactions were moderate and transient; complement-fixing and agglutinating antibodies developed to low titres; two animals aborted; two remained uninfected.

Group 3 consisted of ten animals vaccinated subcutaneously with "Duphavac". Local reactions were severe; complement-fixing and agglutinating antibodies developed to low titre; incomplete antibodies were present to high titre 38 days after the second vaccination; none aborted; seven remained uninfected.

Group 4 consisted of five unvaccinated controls. Four aborted; four developed agglutinating and complement-fixing antibodies to significant titre; one remained uninfected.

\section{Discussion}

Although a variety of non-living preparations from Brucella abortus have been shown to protect mice and guinea-pigs against challenge, very few of these have been tested in cattle under controlled experimental conditions. However, it has been shown conclusively that vaccines made from whole killed organisms emulsified in mineral oil will protect cattle, but provoke considerable reaction around the inoculation site. Whole killed cells without adjuvant do not appear to have been tried, perhaps because their poor performance in laboratory animals made it difficult to justify the expense of a trial in cattle. What little evidence there was did not suggest that extracts without adjuvant were likely to be effective in cattle, even when they had been shown to induce a high degree of immunity in guinea-pigs (Paterson and Pirie, 1948; McDiarmid, 1949). It seemed of questionable value, therefore, to continue accumulating data on the immunisation of laboratory animals until some of the more interesting preparations had been tested in cattle. 


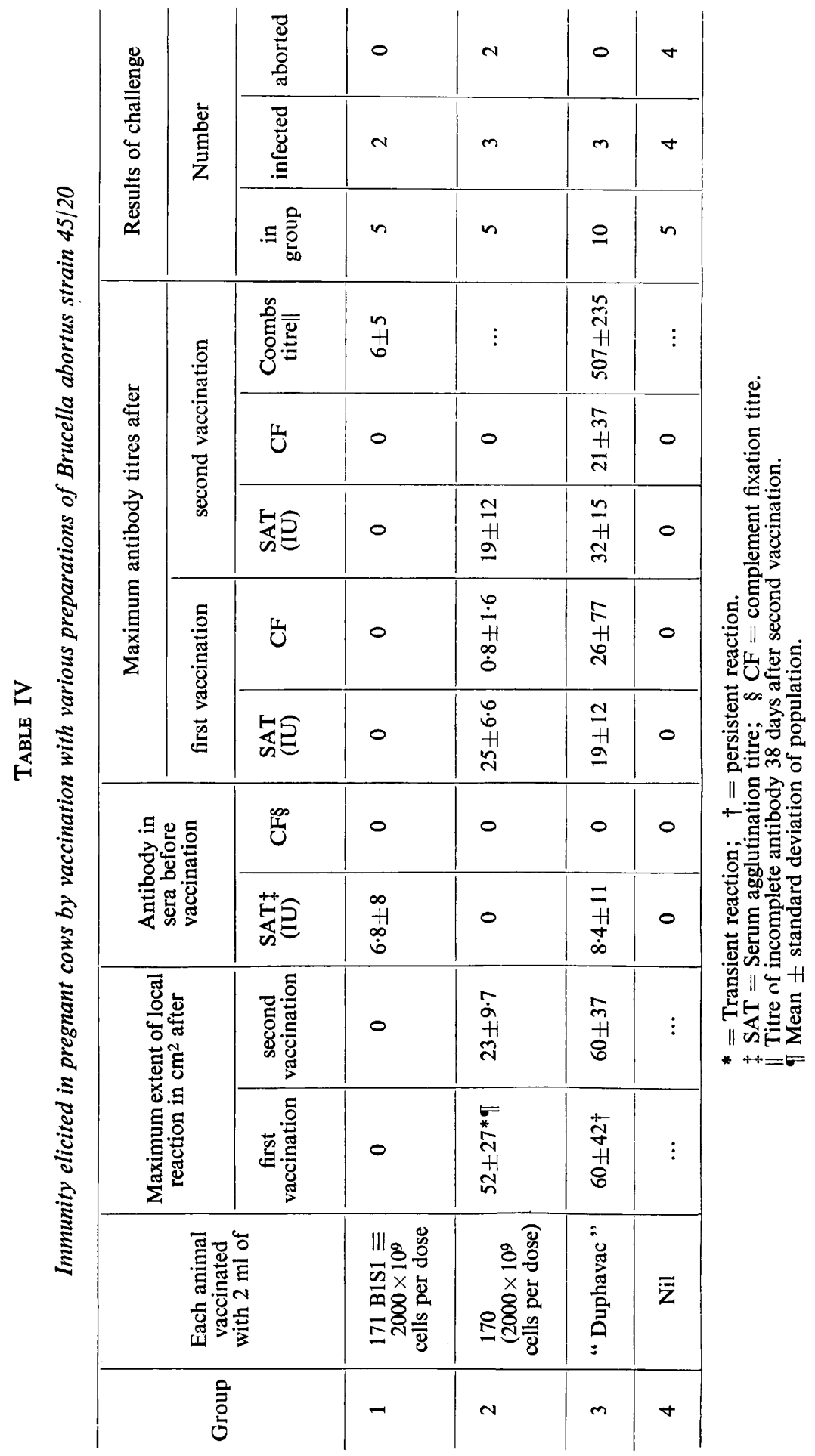


We compared (table IV) the abilities of an extract (lot 171B1S1), of a killed whole-cell suspension (lot 170), and of a killed whole-cell emulsion vaccine ("Duphavac") to immunise pregnant cattle against challenge with virulent $B r$. abortus. All three vaccines were prepared from the rough non-agglutinogenic strain $45 / 20$, but only the "Duphavac" was combined with an adjuvant. A relatively crude extract was chosen for this trial because further purification would have necessitated the testing of several fractions in cattle, because little confidence could be placed in screening tests in laboratory animals.

The chief criterion for selecting this particular extract was its low content of lipopolysaccharide. It was already clear, as a result of the successful use in the field of vaccines prepared from the rough strain $45 / 20$, that the smooth $O$ somatic antigen was not concerned in the immunisation of cattle, despite its ability to induce substantial protection in laboratory animals (Ellwood et al., 1967). It was possible, therefore, that an extract devoid of lipopolysaccharide might induce adequate immunity in cattle without provoking the formation of agglutinins. The formolised whole-cell suspension was included in the trial without added adjuvant because the existing evidence of the need for powerful adjuvants had been obtained from experiments in mice and guineapigs, not from experiments in cattle.

In the trial in cattle, the extract, lot 171B1S1, induced a substantial immunity, caused no local or general reaction, and was completely non-agglutinogenic. In this respect it differed from the highly agglutinogenic preparation described by Ellwood et al. and discussed by Keppie (1969) who considered that their immunogen (extracted from the smooth virulent $B r$. abortus strain 544) was probably the smooth O-antigen.

Although our preparation, lot 171B1S1, was not pure, it is possible to set upper limits to the amounts of certain substances present. The main differences between this material and the immunogenic fraction investigated by Ellwood et al. were the low lipid and high carbohydrate content- 1.7 and 48 per cent. compared with 52 and 10 per cent.-and the absence of amino sugars and formyl groups. It could be assumed that lipopolysaccharide did not play a significant part in the protection induced by lot $171 \mathrm{~B} 1 \mathrm{~S} 1$, an assumption supported by the inability to demonstrate a rapidly sedimenting component by ultracentrifugation.

The use of the rough strain $45 / 20$ ensured the absence of smooth $\mathrm{O}$ agglutininogen from our extract. This does not imply that lipopolysaccharide is absent from strain $45 / 20$, because up to 45 per cent. lipid could be demonstrated in extracts made from strain 45/20 by Ellwood's method (Dr J. Milerová, personal communication).

Ellwood et al. remarked on the resemblance, chemically, of their preparation to that of Paterson et al. (1947), which, too, was highly protective in guineapigs, but failed to immunise cattle, in which it provoked severe and persistent local and general reactions. Lot 171B1S1, on the other hand, which protected cattle, was relatively ineffective in guinea-pigs and only moderately effective in mice. The data do not suffice to characterise the immunogen, since, for obvious reasons, it was not practical to test highly purified material in this 
preliminary experiment in cattle. However, it might be tentatively deduced that the immunogen is not a lipopolysaccharide or lipopolysaccharide-protein complex, but that it could be a small protein, or a glucoprotein or, less probably, a polysaccharide.

The whole-cell suspension lot 170 may have induced some protection despite the absence of any adjuvant. If this were confirmed, it might be that such protection could be adequately enhanced by adjuvants less powerful and less reactive than the oily emulsions considered necessary at present. Frahm and Lembke (1955), for example, protected cattle with an acetone-killed suspension of a smooth Brucella abortus strain in aluminium hydroxide.

Very few of the very many preparations from $B r$. abortus that have been found to immunise laboratory animals have been tried in cattle. A properly organised trial takes $12-15$ mth from the time the animals are selected and screened, through immunisation, insemination and challenge, until abortion or parturition, and finally to examination to exclude or establish infection. Support and facilities for such experimentation are not easily found. Thus, even a small trial, such as that reported here, acquires a somewhat disproportionate importance.

\section{SUMMARY}

Several extracts prepared by the action of surface active agents on live cells of the rough $B r$. abortus strain $45 / 20$ were found to protect mice and guinea-pigs against challenge with virulent $\mathrm{Br}$. abortus. Incorporation in oily emulsions made little difference to the degree of immunity elicited.

An extract prepared by treatment of living cells of strain $45 / 20$ with sodium dodecyl sulphate followed by ethanol precipitation induced substantial immunity in cattle, despite the fact that no adjuvant was used. The extract was devoid of the smooth $\mathrm{O}$ somatic antigen and probably free from lipopolysaccharide. The high protein and carbohydrate content suggested that the immunogen could be a glycoprotein.

We should like to acknowledge the support given by Mr J. C. Malone and Mr C. B. Hart of the Cooper Technical Bureau in organising the cattle experiment in difficult circumstances. Mr Brendan Cunningham of the Veterinary Research Laboratories, Abbotstown, Eire, both suggested and carried out the Coombs testing, and has been unstinting in his help. We also welcome this opportunity of thanking Dr A. McDiarmid of Compton for carrying out the challenge on the cattle and for many useful discussions. We owe much to the help of many colleagues at these laboratories and in particular to Mr Pink and Dr Hampson for many analyses, and to Mrs Eileen Ward for ungrudging and invaluable assistance.

\section{REFERENCES}

Ellwood, D. C., KePpIE, J., ANd Smith, H. 1967. The chemical basis of the virulence of Brucella abortus. VIII. The identity of purified immunogenic material from culture filtrate and from the cell-wall of Brucella abortus grown in vitro. Br. J. Exp. Path., 48, 28.

FrahM, H., AND LemBKe, A. 1955. Die Immunisierung des Rindes gegen Brucellose II Mitteilung. Weitere Erfahrungen mit dem Adsorbat-Impfstoff aus abgetöteten Brucellose-Erregern im Vergleich zur Impfung mit lebenden Kulturen. Zentbl. Bakt. Parasit$K d e$, Abt. I, Orig., 164, 481. 
JeNKIN, C. R., AND Rowley, D. 1965. Partial purification of the "protective" antigen of Salmonella typhimurium and its distribution amongst various strains of bacteria. Austral. J. Exp. Biol. Med. Sci., 43, 65.

KePPIE, J. 1969. Host resistance in experimental brucellosis. Proc. Roy. Soc. Med., 62, 289.

KePPIE, J., WITT, K., AND SMITH, H. 1963. Cross immunization of guinea-pigs with products of Brucellae abortus, melitensis and suis. Br. J. Exp. Path., 44, 84.

MCDiARmid, A. 1949. A comparison of the immunising value in cattle of dead antigens and S.19 Br. abortus vaccine. Vet. Rec., 61, 305.

McDiarmid, A., AND Sutherland, F. B. 1957. A comparison of the immunity produced in guinea-pigs by the inoculation of living heat-killed and adjuvant vaccines prepared from Br. abortus strains 45/20 and S.19. Vet. Rec., 69, 1067.

McEwen, A. D., AND Roberts, R. S. 1936. Bovine contagious abortion. The use of guinea-pigs in immunisation studies. J. Comp. Path. Ther., 49, 97.

MCEwen, A. D., AND SAMuel, J. M. 1955. Brucella abortus: heat stable protective antigen revealed by adjuvant and present in a "rough" variant, strain 45/20: immunisation experiments on guinea-pigs. Vet. Rec., 67, 546.

Markenson, J., Sulitzeanu, D., AND Olitzki, A. L. 1962. Immunogenic activity of brucella cell wall. Br.J. Exp. Path., 43, 67.

Milerová, Jaroslava 1969. Experimental study on the protective antigen derived from the vaccine strain Brucella abortus B.A.19. Proc. X Int. Congr. Microbiol. Standardn, 1967, Prague, p. 269.

Paterson, J. S., ANd Pirie, N. W. 1948. Attempted active immunisation of cattle against Br. abortus infection with an antigenic fraction. J. Comp. Path. Ther., 58, 227.

Paterson, J. S., Pirie, N. W., and Stableforth, A. W. 1947. Protective antigens isolated from Br. abortus. Br. J. Exp. Path., 28, 223.

Pilet, C., ANd Le Garrec, Y. 1963. Sur les propriétés immunisantes des parois de Brucella abortus souche 45/20. I. Obtention des parois. Bull. Acad. vét. Fr., 36, 253.

RoERINK, J. H. G. 1967. Investigation into the usefulness of the non-agglutinogenic Brucella abortus adjuvant vaccine Duphavac N.A. in the control of bovine brucellosis. Vet. Rec., 80, 727.

Smith, H., Keppie, J., Pearce, J. H., ANd Witt, K. 1962. The chemical basis of the virulence of Brucella abortus. IV. Immunogenic products from Brucella abortus grown in vivo and in vitro. Br. J. Exp. Path., 43, 538. 